\title{
STRATIGRAPHY AND BRACHIOPOD FAUNA OF THE CARBONIFEROUS EL IMÁN FORMATION, COLOMBIA
}

\author{
Lucia ANGIOLINI', Patrick R. RACHEBOEUF ${ }^{2}$, \\ Carlos A. VILLARROEL $L^{3}$ and Ana Elena CONCHA ${ }^{3}$
}

\author{
${ }^{1}$ Universita degli Studi di Milano, Dipartimento di Scienze della Terra, Via \\ Mangiagalli 34, I-20133 Milano, Italy. lucia.angiolini@unimi.it \\ ${ }^{2}$ Université de Bretagne Occidentale, UFR Sciences et Techniques UMR 6538, \\ 'Domaines Oceaniques', CNRS Avenue Le Ceorgeu, BP 809 F-29285 Brest \\ cedex, France.patrick.racheboeuf@univ-brest.fr \\ ${ }^{3}$ Departamento de Geociencias, Universidad Nacional de Colombia, Apdo \\ Aéreo 14490, Bogóta, Colombia. cvilla@ciencias.ciencias.unal.edu.co
}

Angiolini, L., Racheboeuf, P.R., Villarroel, C.A. and Concha, A.E. 2003. Stratigraphy and brachiopod fauna of the Carboniferous El Imán Formation, Colombia. [Estratigrafía y braquiópodos de la Formación El Imán, Carbonífero de Colombia.] Revista Española de Paleontología, 18 (2), 151-158. ISSN 0213-6937.

\begin{abstract}
The three main outcrops of the El Imán Formation (Departamento de Tolima, central western Colombia) are fully described and revised. The study of a newly collected brachiopod fauna from the upper outcrop of the El Imán Formation, indicates a Carboniferous age (late Bashkirian-Moscovian) for the upper part of the El Imán Formation at the type locality. Although the fauna is not abundant, has low diversity, and is poorly preserved, the Bashkirian-Moscovian age is deduced from the association of the brachiopod genera Fimbrinia (Productida), Orthotichia (Orthida) and Alispirifer (Spiriferida). These occurrences affirm zoogeographic relationships between Australia and South America during the Late Carboniferous.
\end{abstract}

Keywords: Brachiopods, biostratigraphy, Carboniferous, El Imán Formation, Colombia.

\section{RESUMEN}

Se describe la sucesión litoestratigráfica de los tres afloramientos más importantes de la Formación El Imán (Departamento Tolima, centro oeste de Colombia) y se revisa dicha formación. La fauna de braquiópodos que se describe aquí por primera vez es indicadora de una edad Carbonífero (Bashkiriense-Moscoviense) para la parte superior de la Formación El Imán. Aunque la fauna sea poco diversa, escasa y mal conservada, la edad Bashkiriense tardio-Moscoviense se deduce de la asociación de los generos Fimbrinia (Productida), Orthotichia (Orthida) y Alispirifer (Spiriferida). Estos braquiópodos indican relaciones zoogeográficas entre Australia y America del Sur durante el Carbonífero tardio.

Palabras clave: Braquiópodos, bioestratigrafía, Carbonífero, Formación El Imán, Colombia.

\section{INTRODUCTION}

Globally speaking, the most important studies on the Palaeozoic of Colombia were done during the 1960-70's with papers dealing with lithology, chronostratigraphy and biostratigraphy of most of the rocks assigned to the Paleozoic. However, progress in more regional geologic studies, within a dynamic context, marked the importance of multidisciplinary studies. The present work takes place in such a perspective.

Carboniferous strata in Colombia are distributed as isolated outcrops, often as structural wedges, associated with the main igno-metamorphic massifs of the Oriental Cordillera (Villarroel and Mojica, 1987). Successions are always incomplete and restricted geographically. Outside this geologic context, localities exposing Carboniferous 


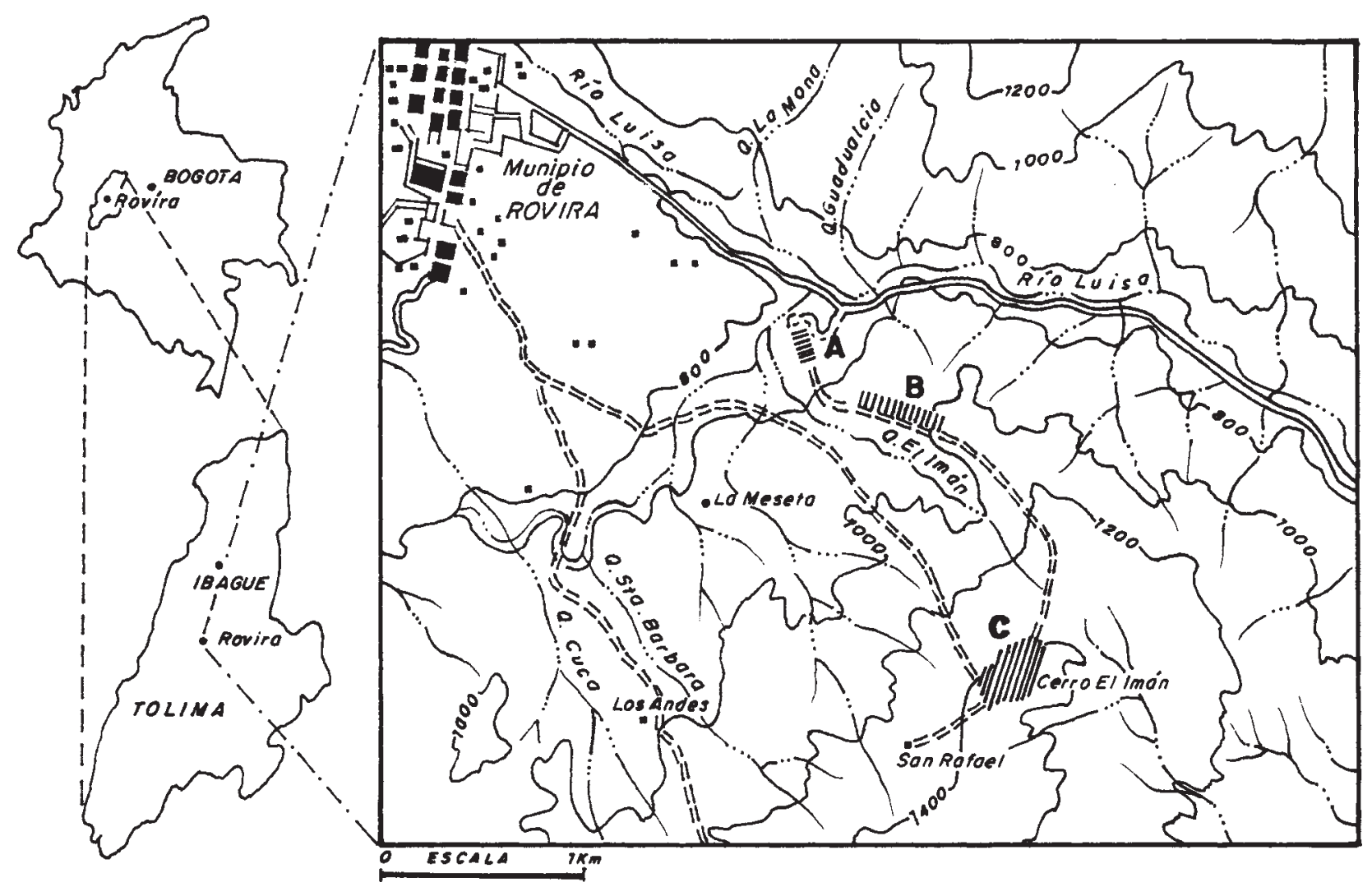

Figure 1. Localisation map of the Carboniferous metasediments of Rovira. A: Lower outcrop; B: Middle outcrop; C: Upper outcrop of the Cerro El Imán which yields the brachiopod-bearing beds.

sequences are rare; among these are the rocks of the Cerro El Imán (Rovira) and the succession of the Serranía de Las Minas, both located on the oriental side of the Central Cordillera.

Since their discovery, the metasediments of the Cerro El Imán were successively assigned to the Middle-Upper Devonian (Forero, 1970, p. 142), then to the Upper Devonian (Frasnian-Famennian; Forero, 1986; 1991, p. 109), or to the Devonian without further precision (Barrett, 1988, p. 708). A Late Carboniferous age (BashkirianMoscovian), is proposed herein for the first time on the basis of brachiopods.

\section{LITHOLOGY AND STRATIGRAPHY OF THE EL IMÁN FORMATION}

\section{by Carlos Villarroel and Ana Elena Concha}

\section{Type locality}

According to Nuñez et al. (1984), the El Imán Formation, which yields the fauna described below, was initially proposed by Nuñez and Murillo (1982), in an unpublished Report of Ingeominas ( $\left.\mathrm{n}^{\circ} 1879\right)$, to designate « ... una secuencia sedimentaria, que aflora en el cerro El Imán y las quebradas El Imán, San Rafael y Bolaños, en la región NE de la plancha 263. गThe type locality of this lithologic unit, as clearly established by the authors, includes El Imán hill and El Imán ravine, situated $4.2 \mathrm{~km} \mathrm{SE}$ of Rovira (Fig. 1). Rovira is a small town located in the central part of Tolima department, $22 \mathrm{~km}$ south of Ibagué City. The geographic coordinates of the El Imán hill are $4^{\circ}, 14^{\prime}, 43^{\prime \prime}$ $\mathrm{N}$, and $75^{\circ}, 16^{\prime} 25^{\prime \prime} \mathrm{W}$.

\section{Lithostratigraphy of the EI Imán Formation at the type locality}

Most Paleozoic outcrops of Colombia occur as isolated tectonic wedges and/or are affected by intrusive igneous rocks which make reconstruction of the Paleozoic sequence difficult. Rocks of the El Imán Formation have been dislocated by an intrusive igneous massif, and they were weakly affected by metamorphism. Moreover they lie as small isolated blocks backed onto the intrusive massif without any apparent order. Such conditions preclude the reconstruction of the original Carboniferous succession.

From bottom to top, Forero (1970) recognized three units within the rocks outcropping on El Imán hill, namely: " a)Areniscas cuarcíticas y conglomerados », about $70 \mathrm{~m}$ thick; « b) Shales negros fosilíferos », $30 \mathrm{~m}$ thick, yielding bryozoan remains and poorly preserved brachiopods, and « c)Areniscas y arcillolitas fosilíferas ». 
Along the mule track which climbs up the NW side of El Imán hill, rocks assigned to the El Imán Fm. outcrop discontinuously as metasedimentary fragments. According to their lithology and relative position, three units can be distinguished. These isolated small outcrops are backed up to the « Stock Granítico del Sur de Rovira » which is mainly a granodiorite with quartzo-monzonitic to granitic differentiations (Nuñez et al., 1984). Following other authors, we consider herein that the three units recognized are parts of the same El Imán Formation.

From their relative superposition it is logical that the unit which outcrops at the top of El Imán hill would be stratigraphically above the two other units. However, it cannot yet be established whether the three units belong to the same continuous succession, or if they are only isolated parts from distinct levels within the original succession. Similarly, the respective position of each of the three units in the lithologic column of the El Imán Formation remains uncertain because the lower and upper limits of the formation are still unknown.

Fracturing is so intense within the two lower units that stratification can be only locally observed, and when strike and dip can be measured, they strongly vary, and no reliable thickness can be established. The upper unit which outcrops at the top of El Imán hill, and which yields the brachiopod fauna described below, is less tectonically affected and it shows a weak plunge towards the NW. However, metamorphism and weathering have developed enough to cancel original lithology and stratification as well.

Lithologic identification of the three units is difficult, using only a standard binocular microscope (x 10). Indeed, original sediments have been weakly metamorphosed and this fact implies the use of the prefixe meta- for the identified rocks, as well as the use of a petrographic microscope.

Two thin sections of the grey-blue lower unit, which outcrops on the NW side of El Imán hill (Fig. 1), corresponding to interbedded beds have been studied. The DR-1 thin section exhibits a meta-arenite with discontinuous intercalated calc-schist levels. Fine, well-sorted, angular to subrounded quartz grains, represent 65\%; their sphericity index is low. The clayey matrix, partly sericitized, represents about $15 \%$ of the whole rock; the remaining $15 \%$ are composed of micaceous-carbonate material and muscovite, the last $5 \%$ being represented by accessory minerals including iron oxydes, zircon, sphene and opaque minerals.

The second thin section (DR-2) also corresponds to a meta-arenite in which small, well-sorted, subangular to subrounded, quartz grains have a low sphericity index. They represent about $85 \%$ of the rock, while sericite, resulting from metamorphism of the original clayey matrix, does not exceed 7\%. Similarly, percentages of clayey-car- bonates and accessory minerals (pyrite, hematite, sphene, zircons, and secondary quartz veins) decrease from $5 \%$ to $3 \%$ respectively. In both thin sections (DR-1 and DR-2), quartz grains are arranged in small isolated groups within the metamorphosed clayey matrix. Limits between grains appear like elongate sutures, with triple points, indicative of weakly dynamic metamorphism. The existence of a previous regional metamorphism cannot be established.

Three thin sections of the middle unit have been studied. Thin section DR-3 is a poorly-sorted, coarse-grained to conglomeratic meta-arenite. Rounded quartz grains represent $90 \%$ of the whole rock, of which $85 \%$ are monocristalline, while the remaining $15 \%$ are polycristalline. This suggests the occurrence of quartzitic rocks in the source area. Such a source area may have been part of the Central Cordillera which actually includes Precambrian cores with similar rocks. Scattered sericite grains, derived from the metamorphosed original clayey matrix do not exceed $9 \%$, while the remaining $1 \%$ is composed of volcanic fragments. The average size of quartz grains is about $1.5 \mathrm{~mm}$, though some grains may reach $4 \mathrm{~mm}$.

The two other thin sections of the middle unit (DR-4 and DR-5) show that the conglomeratic meta-arenites are associated with weakly laminated clayey calc-schist. Metaclay include $85 \%$ to $90 \%$ sericite and illite; the remaining $10 \%$ to $15 \%$ are composed of half biotite and half quartz grains. The size of quartz grains is intermediate between mud and clay. Sericite exhibits two perpendicular schistosity directions.

The yellowish and reddish metasediments outcropping at the top of El Imán hill are those which yield the best preserved fossils. Petrologic analysis of thin section DR6 shows that it is a meta-clay in which sericite represents $70 \%$, and very thin quartz grains $23 \%$. Muscovite and plagioclase represent $2 \%$ respectively, the remaining $3 \%$ being opaque minerals (iron oxydes). Like in the similar metasediments of the middle unit, sericite exhibits two perpendicular schistosity directions, and some quartz grains are fractured. These two last characters indicate weak dynamic metamorphism.

\section{Age and correlations}

Metamorphism of the El Imán Formation makes comparison with other Carboniferous sedimentary units of Colombia difficult. An exception may be the so-called «Grupo Chundua» which outcrops in the Sierra Nevada de Santa Martha, also weakly affected by metamorphism (Julivert, 1968, p. 259). However, the uppermost part of the Chundua Group yields limestones and marbles suggesting that this unit may be younger, as limestones are more commonly developed in upper Carboniferous and Permian strata in the area.

According to the fact that the Amoyá Formation ([first described by Nuñez et al., 1984, E of Rovira] and assigned to the Middle Devonian according to palynology [Pross] 
and Gossler, 1995]), and the El Imán Formation were deposited contemporaneously (the age of the El Imán Fm was earlier assigned to the Middle and Upper Devonian), Prossl and Grosser proposed (1995, p. 97) to include the rocks of El Imán hill in the Amoyá Fm. Such a position cannot be sustained because of lithologic differences; moreover if a Middle Devonian can be assigned to the Amoyá Fm. (according to Prossl and Grosser, 1995), a late Bashkirian-Moscovian age is assigned herein to the El Imán Formation.

We conclude that sediments of the El Imán Fm. deposited at the beginning of the last Paleozoic marine trangressive event, immediately following the Famennian to late Mississippian gap in sedimentation. Studies of fishes (Janvier and Villarroel, 2000), and plant remains (Berry et al., 2000) from the Cuche Fm. (GivetianFrasnian of he Floresta area, NE of Bogota) support the idea of a global sealevel drawdown in that the Devonian sea receded from NW South America during the Frasnian and/or the Famennian.

A late Bashkirian-Moscovian age for the El Imán metasediments, is the oldest date proposed up to now for the Pennsylvanian-Permian transgression following the Mississippian gap, as it appears clearly in the comparative stratigraphic scheme established by Villarroel and Mojica (1987, Fig. 3). Cediel (1972), however, suggested that marine sedimentation was continuous from Devonian up to Permian. It is impossible to state if the FamennianMississippian gap is related to the Hercynian Orogeny. This stratigraphic gap is almost an equivalent to the «Fase Chiriguana» of the upper Paleozoic orogeny of Bolivia in central South America (Suarez Soruco, 2000, p. 214: Esquema Geocronológico de Bolivia).

\section{SYSTEMATIC PALEONTOLOGY}

\author{
by Lucia Angiolini \\ and Patrick R. Racheboeuf
}

All figured specimens are housed in the collection of the Universidad Nacional de Colombia, Departamento de Geociencias ( $\left.{ }^{\circ} \mathrm{UN}-\mathrm{DG}\right)$.

ORDER PRODUCTIDA Waagen, 1883 SUBORDER PRODUCTIDINA Waagen, 1883 SUPERFAMILY PRODUCTOIDEA Gray, 1840

Family Productellidae Schuchert, 1929

Subfamily Overtoniinae Muir-Wood and Cooper, 1960

Tribe Overtoniini Muir-Wood and Cooper, 1960. Genus Fimbrinia Cooper, 1972
Fimbrinia sp.

Figs. 2i-j, 1-n

Material: Three specimens: the two casts of a dorsal valve (UN DG 755 and 756; Fig. 2, i-j), the internal and external casts of a distorted dorsal valve (UN DG 757 and 758; Fig. 2, m-n), and the two external casts of a distorted, articulated shell (UN DG 759; Fig. 2, 1, and UN DG 760).

Description: Small-sized, concavo-convex shell with deep corpus cavity. Ventral valve with narrow and recurved umbo. Dorsal valve wider than long, weakly concave, with the concave longitudinal profile more accentuated in the posteromedian part of the valve, below the umbo. Ventral valve ornamented by rugae, becoming lamellose anteriorly and bearing stout recumbent spines, arranged in concentric rows. Dorsal valve ornamented by srong lamellose, concentric bands bearing finer spines and few dimples. The best preserved dorsal valve exterior is $14 \mathrm{~mm}$ wide and $10 \mathrm{~mm}$ long and exhibits nine concentric lamellose bands. On both valves recumbent spines are displayed on a single concentric row, between each concentric lamellae. Ventral spines number 3 to 4 per mm. Dorsal spines are much more finer, and more closely spaced but their density is almost the same as on the ventral valve.

Ventral valve interior unknown.

Dorsal valve interior deeply impressed by the external concentric lamellae, with rather strong marginal ridges extending to the ears. Low and thin median septum not extending anteriorly beyond midlength of the valve, separating two raised, subtriangular, rounded adductor scars. Inner socket ridges low and narrow, rounded and laterally elongated, parallel to hinge line. Surface of the valve covered with numerous, radially arranged, endospines. Cardinal process sessile, trifid, directed posteriorly.

Discussion: The Colombian specimens display the generic characters of the genus Fimbrinia, and probably represent a new species. They differ from the type species $F$. plummeri (King, 1938), by more pronounced lamellose bands in the dorsal valve, by a dorsal ornamentation with fewer dimples and by lateral ridges that do not curve anteriorly at the base of the cardinal process. The genus Fimbrinia is reported to occur in the Late Carboniferous and Early Permian of North and South America (Muir-Wood and Cooper, 1960; Brunton et al., 2000) and in the late Bashkirian through early Moscovian of the Canadian Arctic Archipelago (Carter and Poletaev, 1998). A certain similarity exists with the levipustulinid genera Bulahdelia Roberts (in Roberts et al., 1976) and Levipustula Maxwell, 1951 from the Early and Late Carboniferous of Eastern Australia (Brunton et al., 2000). However, the Colombian specimens do not show quincuncially arranged spines and have stronger lamellose bands on both valves.

? Subfamily Productininae Muir-Wood and Cooper, 1960

? Tribe Productinini Muir-Wood and Cooper, 1960 

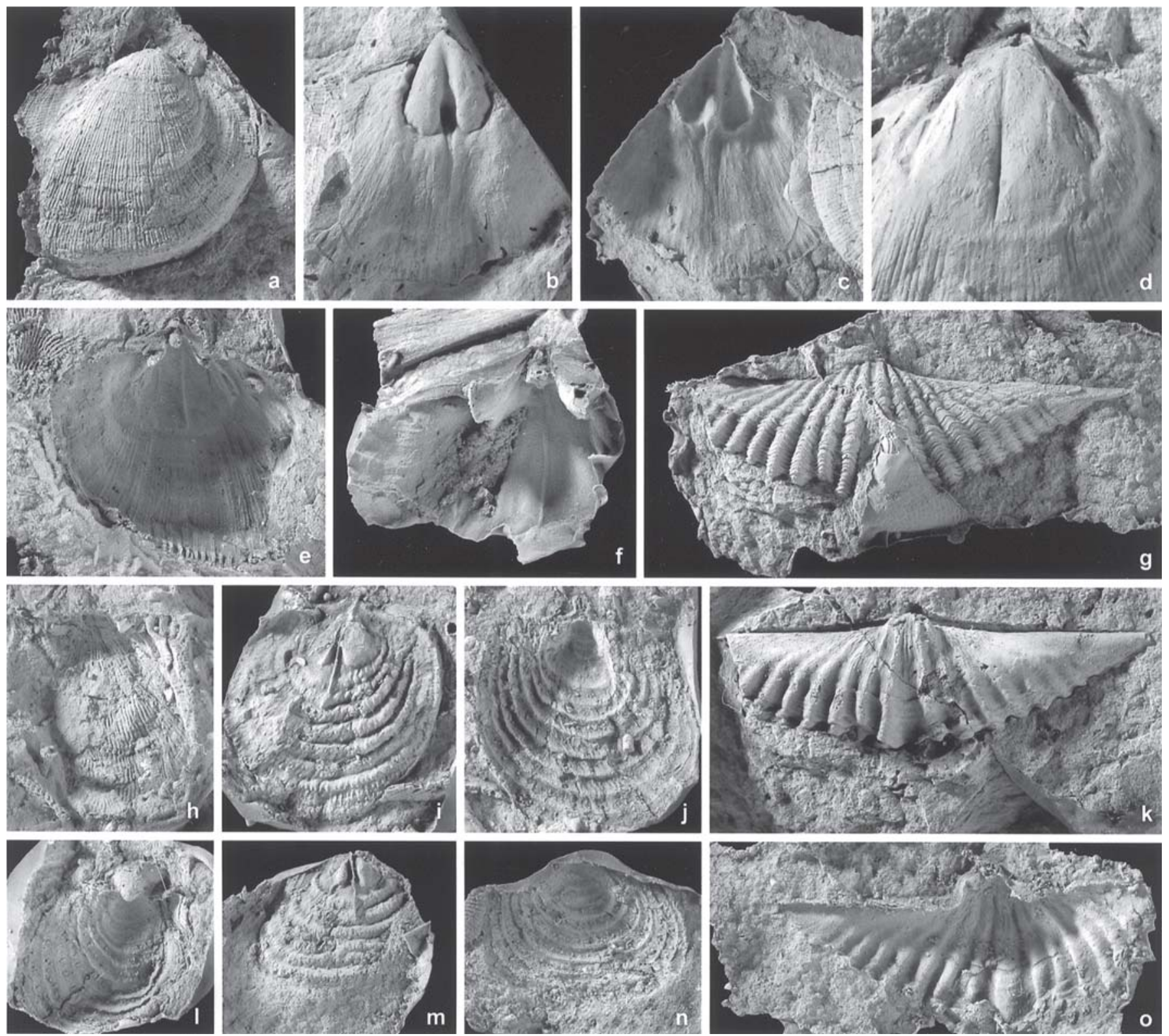

Figure 2. Brachiopods from the Cerro El Imán.

a-f: Orthotichia sp. a: ventral valve exterior, latex, x 2, UN-DG 775. b-c, ventral valve interior, internal mould (b) and latex (c), x 2, UN-DG 764. d-e, dorsal valve interior; d, enlarged view of the postero-median part of the internal mould (x 3); e, latex (x 2), UN-DG 776. f, posterior part of an incomplete dorsal valve, latex, x 3, UN-DG 787.

g, k, o: Alispirifer cf. transversus Maxwell, 1964, x 1,5: ventral valve exterior, latex cast (g), internal mold of the same (k), and latex cast of the interior (o), UN-DG 781 .

h: Productida, gen. and sp. indet.: dorsal exterior of a distorted articulated shell, latex cast, x 2, UN-DG 797.

i, j, l-n: Fimbrinia sp., x 2: i-j, dorsal valve, latex casts of the interior (i), and exterior (j), UN-DG-755 y 756 . 1, dorsal view of an articulated, distorted shell, latex, x 2, UN-DG 759. m-n, latex casts of a dorsal valve, interior (m), and exterior (n), UN-DG-757 y 758.

\section{Productida genus et species indet.} Fig. $2 \mathrm{~h}$

Material: A single fragment of a crushed articulated shell (UNDG 797; Fig. 2, h), and external cast of a badly preserved dorsal valve (UN-DG 805).

Description: Shell small with markedly concave dorsal valve, with maximum width at hinge line (length $=13 \mathrm{~mm}$; corresponding width $=15 \mathrm{~mm}$ ). Myophore of the cardinal process relatively large and prominent, deeply bilobed, in dorsal position. Shell surface covered by thin, regular, low and rounded radial ribs ( 3 to 4 per $\mathrm{mm}$ along anterior margin), increasing mainly by intercalation. Concentric rugae developed towards the periphery of the valve, mainly posterolaterally. No spine could be observed. 
Discussion: Shell size, concavity of the dorsal valve, and especially the morphology and arrangement of radial ribs, recall the genus Productina Sutton, 1938, of the Tribe Productinini. Productina is known from the Upper Devonian-Lower Carboniferous (Hastarian) of North America, Europe, Australia and ?northern Africa (Brunton et al., 2000).

ORDER ORTHIDA Schuchert and Cooper, 1932 SUPERFAMILY ENTELETOIDEA Waagen, 1884

Family Schizophoriidae Schuchert and Le Vène, 1929 Genus Orthotichia Hall and Clarke, 1892

Type species: Orthis (?) morganiana Derby, 1874.

\section{Orthotichia sp.}

Fig. 2a-f

Material: Thirty-seven more or less complete, often tectonically distorted and fragmentary isolated ventral and dorsal valves, preserved as natural external and internal casts (UN DG 752, 754, 763, 764: Fig. 2, b-c; 765, 770-772, 774, 775: Fig. 2, a; 776: Fig. 2, d-e; 785, 786, 787: Fig. 2, f; 788-795, and 803-806).

Description: Large, unequally biconvex shell, with rather flat ventral valve. Maximum width at about midlength. Anterior commissure uniplicate. Ventral valve with pointed umbo and narrow interarea nearly perpendicular to plane of commissure.

Dorsal valve convex, with sharply bended anterior margin. Ornamentation finely multicostellate with about 16-18 costellae per $5 \mathrm{~mm}$ at midlength. Tubular slightly coarser costellae occurs on both valves. Regularly spaced grow lamellae.

Interior of ventral valve with straight dental plates extending forward to completely enclose a narrow, elongate, bilobed muscle field bisected by a medium septum, that does not extend beyond the anterior ends of ventral adminicula. The median septum is raised and thickened at its distal end.

Interior of dorsal valve with strong and divergent brachiophore plates confining the muscle field, and a long myophragm. Two small, pear-shaped to oval scars occur in the anterior part of the muscle field, whereas two raised, elongated scars are present along the base of the brachiophore plates. Cardinal process prominent.

Discussion: These specimens are included in the genus Orthotichia because of their finely multicostellate ornamentation, their long and straight dental plates, with ventral adminicula extending to in front of muscle field, and the well developed median septum, raising to a crest at its anterior end. Furthermore, they show the same pattern of the 'tripartite' dorsal muscle field of Orthotichia morganiana (Derby, 1874, pl. III, fig. 1-5), the type-species, from the Late Carboniferous Coal Measures of Itaituba, Brazil. However the type-species shows finer and more numerous costellae besides a much inflated shape.

The similar genus Schizophoria King, 1850 shows more divergent and shorter dental plates and a less devel- oped ventral septum. Among the Schizophoriidae, the Permian genera Acosarina Cooper and Grant, 1969 and Kotlaia Grant, 1993 are also closely related to Orthotichia. However, both are smaller with sulcate or emarginate commissure and differently developed dental plates and ventral septum. Kotlaia has a very long ventral septum extending to the anterior margin.

ORDER RHYNCHONELLIDA Kuhn, 1949 SUPERFAMILY RHYNCHOPOROIDEA Muir-Wood, 1955

Family Rhynchoporidae Muir-Wood, 1955 Genus Rhynchopora King, 1865

Type species: Terebratula geinitziana de Verneuil, 1845.

\section{Rhynchopora sp.}

Material: an internal mold of a ventral valve, on sample UN DG 752 (together with a specimen of Orthotichia).

Remarks: The occurrence of the genus Rhynchopora is indicated by the presence of a single valve with flaring outline and with coarse ribs widening anteriorly, numbering at least 2 on the sulcus and 3 on each flank. Internally the ventral valve shows dental plates. The specimen exhibits poorly preserved endoponctuation (Savage, 1996).

\section{ORDER SPIRIFERIDA Waagen, 1883}

Only two isolated valves of spiriferid brachiopods have been collected. The largest one is described below. The second specimen (UN DG 766) is an internal natural cast of a very small dorsal valve (6 mm wide), very badly preserved, which exhibits four rounded costae on each flank.

SUBORDER SPIRIFERIDINA Waagen, 1883
SUPERFAMILY PAECKELMANNELLOIDEA

Ivanova, 1972

Family Srophopleuridae Carter, 1974

Subfamily Pterospiriferinae Waterhouse, 1975

Genus Alispirifer Campbell, 1961

Type species: Alispirifer laminosus Campbell, 1961.

\section{Alispirifer cf. transversus Maxwell, 1964}

Fig. 2g, k, o

Material: External and internal natural casts of a ventral valve (UN DG 779-781).

Description: Ventral valve markedly convex longitudinally, very transverse in outline, with maximum width at hinge line. Length $=15 \mathrm{~mm}$; width (est.) $=51 \mathrm{~mm}$. 'U'-shaped shallow sulcus 
about $5 \mathrm{~mm}$ wide along anterior margin. Ornamentation of simple rounded costae tapering and becoming indistinct towards cardinal extremities. Eight, possibly nine, costae on each flank. Shell surface covered by very thin, dense and regularly spaced growth lamellae.

Ventral valve interior with very small, short and thick dental plates. Muscle field rhomboidal in outline, ill-limited anterolaterally, $6 \mathrm{~mm}$ wide and with anterior margin at $7 \mathrm{~mm}$ from the umbo. Diductor scars weakly prominent. Adductor scars long and narrow. Genital markings weakly excavated, elongated and radially arranged.

Dorsal valve unknown.

Discussion: The only available ventral valve is very similar to specimens described by Cisterna (1997) as Alispirifer transversus Maxwell, 1964, from NamurianWestphalian beds of the Las Salinas Formation of the Chubut Province (Argentina). It differs only in subtle details of ornamentation. Alispirifer transversus has been originally described from the Levipustula levis Zone of eastern Australia (Maxwell, 1964), whose base is dated to the Namurian and whose top ranges up to the Moscovian or possibly higher (Roberts et al., 1993). The occurrence of the genus Alispirifer in Colombia confirms the paleobiogeographic relationships between Australia and South America during the mid-Late Carboniferous, which continued during the Earliest Permian as proposed by Cisterna et al. (2002).

\section{CONCLUSION}

Alispirifer cf. transversus confirms a Namurian-Moscovian age, according to the known range of A. transversus. Fimbrinia is known to occur from the late Bashkirian to the Early Permian. Orthotichia ranges from the Late Carboniferous to the Middle Permian. Thus a late Bashkirian-Moscovian age appears likely for the brachiopod assemblage described here.

\section{ACKNOWLEDGMENTS}

We gratefully acknowledge María-Luisa Martínez Chacón and Cor F. Winkler Prins for thoughtful and extensive comments on the manuscript, and Paul Copper for extensive correction of the language. The paper was greatly improved by their efforts. Photos by Noël Podevigne (UMR 5125, Villeurbanne).

\section{REFERENCES}

Barrett, S.F. 1988. The Devonian System in Colombia. In: Devonian of the world (Eds. N.J. McMillan, A.F. Embry and D.J. Glass), Proceedings of the 2nd. International Symposium on the Devonian System, Vol. I: Regional Syntheses. Canadian Society of Petroleum Geologists, 705-717.
Berry, C. M., Morel, E., Mojica, J. and Villarroel, C. 2000. Devonian plants from Colombia, with discussion of their geological and paleogeographical context. Geological Magazine, 137, 257-268.

Brunton C.H.C., Lazarev, S.S., Grant, R.E. and Jin Yu-gan 2000. Productidina. Treatise on Invertebrate Paleontology, Part H Brachiopoda, v. 3, H424-643.

Campbell, K.W.S. 1961. Carboniferous fossils from Kuttung Rocks of New South Wales. Palaeontology, 4, 428-474.

Carter, J. and Poletaev, V. I. 1998. Atokan (Late Bashkirian or Early Moscovian brachiopods from the Hare Fiord Formation of Ellesmere Island, Canadian Arctic Archipelago. Annals of Carnegie Museum, 67, 105-180.

Cediel, F. 1972. Movimientos tectónicos en el intervalo Paleozoico-Mesozoico en Colombia y su influencia en reconstrucciones paleogeográficas. Anais Academia do Brasil, Ciencias, 44, 87-93.

Cisterna, G.A. 1997. Spiriferida (Brachiopoda) en la Formación Las Salinas, Carbonifero superior, Provincia de Chubut, Argentina. Ameghiniana, 34, 155-161.

Cisterna, G.A., Archbold, N.W. and Simanauskas, T. 2002. The Permian brachiopod genus Trigonotreta Koenig, 1825 and its occurrence in Argentina. Ameghiniana, 39, 213-220.

Cooper, G.A.1972. Correction of a brachiopod name. Journal of Paleontology, 46, 450.

Cooper, G.A. and Grant, R.E. 1969. New Permian brachiopoda from west Texas. Smithsonian Contributions to Paleobiology, 1, 1-20.

Derby, O.A. 1874. On the Carboniferous Brachiopoda from Itaituba, Rio Tapajos, Province of Para, Brazil. Cornell University Scientific Bulletin (series 2), 1, 1-63.

Forero, A. 1970. El Paleozoico Superior del flanco oriental de la Cordillera Central. Geología Colombiana, 7, 139149.

Forero, A. 1986. Remanentes de la Provincia Paleobiogeográfica Frasniano-Fameniana del viejo mundo en los Andes septentrionales. Geología Norandina, 10, 35-38.

Forero, A. 1991. Distribución de las rocas del Devónico en los Andes Colombianos. Revista Técnica de YPFB, 12, 101-111.

Grant, R.E. 1993. Permian brachiopods from Khios Island, Greece. Journal of Paleontology, 67, Paleontological Society Memoir, 33, 1-21.

Hall, J. and Clarke, J.M. 1892. An introduction to the study of the genera of Palaeozoic Brachiopoda. Natural History of New York, Palaeontology, 8, 1. New York Geological Survey. Charles van Benthuysen \& Sons. Albany, 367 pp.

Janvier, P. and Villarroel, C. 2000. Devonian vertebrates from Colombia. Paleontology, 43, 729-763.

Julivert, M. 1968. Colombie. Lexique stratigraphique International. Vol. V, Fasc. 4a, Première Partie, 651 pp.

King, W. 1850. A Monograph of the Permian Fossils of England. Palaeontographical Society Monograph, 3, 258 pp.

King, W. 1865. Remarks on the histology of two specimens of Rhynchopora Geinitziana [sic] de Verneuil, from near the river Oukhla, province of Archangel. Annals Natural History, 3 (16), 124-128. 
King, R.H. 1938. New Chonetidae and Productidae from Pennsylvanian and Permian strata of north central Texas. Journal of paleontology, 12, 257-279.

Maxwell, W.G.H. 1951. Upper Devonian and Middle Carboniferous brachiopods of Queensland. University of Queensland Papers (Geology), 3 (14), 1-27.

Maxwell, W.G.H. 1964. The geology of the Yarrol Region. Part 1. Biostratigraphy. University of Queensland Papers, Department of Geology, 4 (5), 1-69.

Muir-Wood, H . and Cooper, G.A. 1960. Morphology, classification and life habits of the Productoidea (Brachiopoda). Geological Society of America, Memoir, 81, 447 pp.

Nuñez, A. y Murillo, A. 1982. Geología y prospección geoquímica de las Planchas 244-Ibagué y 263-Ortega. Ingeominas, Informe Interno No. 1879, Ibahué, 367 pp. Nuñez, A., Mosquera, D. y Vesga, C.J. 1984. Plancha $263-$ Ortega. Ministerio de Minas y Energía. Instituto Nacional de Investigaciones Geologico-Mineras.

Prossl, K.F. and Grosser, J.R. 1995. The age of the Formación Amoyá, Upper Magdalena Valley: Another piece in the Paleozoic stratigraphic puzzle of Colombia. Newsletter on Stratigraphy, 32, 91-101.

Roberts, J., Hunt, J.W. and Thompson, D.M. 1976. Late
Carboniferous marine invertebrate zones of eastern Australia. Alcheringa, 1, 197-225.

Roberts, J., Jones, P.J. and Jenkins, T.B.H. 1993. Revised correlations for the Carboniferous marine invertebrate zones of eastern Australia. Alcheringa, 17, 353-377.

Savage, N.M. 1996. Classification of Paleozoic rhynchonellid brachiopods. In: Brachiopods. Proceedings of the Third International Brachiopod Congress, Sudbury, Canada, 25 September 1995 (eds. P. Copper and J. Jin). Balkema Press, Rotterdam, 249-260.

Suarez Soruco, R. 2000. Compendio de Geología de Bolivia. Revista Técnica de YPFB, 18, 214 pp.

Sutton, A.H. 1938. Taxonomy of Mississippian Productidae. Journal of Paleontology, 12, 537-569.

Verneuil, E. de 1845. Paléontologie, mollusques, brachiopodes. In: Géologie de la Russie d'Europe et des Montagnes de l'Oural ( eds. I. Murchison, E. de Verneuil and A. de Keyserling), John Murray (London), Bertrand (Paris), v. 2, 3, 17-395.

Villarroel, C. y Mojica, J. 1987. El Paleozoico Superior (Carbonífero y Pérmico) sedimentario de Colombia. Afloramientos conocidos y características generales. Geología Colombiana, 16, 81-87.

Manuscrito recibido: 17 de junio, 2002 Manuscrito aceptado: 31 de marzo, 2003 